\title{
inu \\ Optimization of Extraction Conditions and Characterization of Volatile Organic Compounds of Eugenia klotzschiana O. Berg Fruit Pulp
}

Ana P. X. Mariano ${ }^{1}$, Ana L. C. C. $\operatorname{Ramos}^{1}{ }^{\mathbb{D}}$, Afonso H. de Oliveira Júnior ${ }^{2} \mathbb{D}$, Yesenia M. García ${ }^{2}$, Ana C. C. F. F. de Paula ${ }^{3}$, Mauro R. Silva ${ }^{4}$, Rodinei Augusti ${ }^{5}{ }^{(D}$, Raquel L. B. de Araújo ${ }^{1}$ and Júlio O. F. Melo ${ }^{2, *(D)}$

\section{Citation: Mariano, A.P.X.; Ramos,} A.L.C.C.; de Oliveira Júnior, A.H.; García, Y.M.; de Paula, A.C.C.F.F.; Silva, M.R.; Augusti, R.; de Araújo, R.L.B.; Melo, J.O.F. Optimization of Extraction Conditions and Characterization of Volatile Organic Compounds of Eugenia klotzschiana O. Berg Fruit Pulp. Molecules 2022, 27, 935. https://doi.org/10.3390/ molecules27030935

Academic Editor: Hiroyuki Kataoka

Received: 31 December 2021

Accepted: 25 January 2022

Published: 29 January 2022

Publisher's Note: MDPI stays neutral with regard to jurisdictional claims in published maps and institutional affiliations.

Copyright: (C) 2022 by the authors. Licensee MDPI, Basel, Switzerland. This article is an open access article distributed under the terms and conditions of the Creative Commons Attribution (CC BY) license (https:// creativecommons.org/licenses/by/ $4.0 /)$.
1 Departamento de Alimentos, Faculdade de Farmácia, Campus Belo Horizonte, Universidade Federal de Minas Gerais, Belo Horizonte 31270-901, Brazil; anapaula.xavier.mariano@hotmail.com (A.P.X.M.); analuizacoeli@gmail.com (A.L.C.C.R.); raquel@bromatologiaufmg.com.br (R.L.B.d.A.)

2 Departamento de Ciências Exatas e Biológicas, Campus Sete Lagoas, Universidade Federal de São João Del-Rei, Sete Lagoas 36307-352, Brazil; afonsohoj@gmail.com (A.H.d.O.J.); jenny_thesiba@hotmail.com (Y.M.G.)

3 Departamento de Ciências Agrárias, Instituto Federal de Educação, Ciência e Tecnologia de Minas Gerais, Campus Bambuí, Bambui 38900-000, Brazil; ana.paula@ifmg.edu.br

4 Departamento de Nutrição, Pontifícia Universidade Católica de Minas Gerais, Belo Horizonte 30640-070, Brazil; mauroramalhosilva@yahoo.com.br

5 Departamento de Química, Campus Belo Horizonte, Universidade Federal de Minas Gerais, Belo Horizonte 35702-031, Brazil; augusti.rodinei@gmail.com

* Correspondence: onesiomelo@gmail.com

Abstract: Eugenia klotzschiana O. Berg is a native species to the Cerrado biome with significant nutritional value. However, its volatile organic compounds (VOCs) chemical profile is not reported in the scientific literature. VOCs are low molecular weight chemical compounds capable of conferring aroma to fruit, constituting quality markers, and participating in the maintenance and preservation of fruit species. This work studied and determined the best conditions for extraction and analysis of VOCs from the pulp of Eugenia klotzschiana O. Berg fruit and identified and characterized its aroma. Headspace solid-phase microextraction (HS-SPME) was employed using different fiber sorbents: DVB/CAR/PDMS, PDMS/DVB, and PA. Gas chromatography and mass spectrometry (GC-MS) were employed to separate, detect, and identify VOCs. Variables of time and temperature of extraction and sample weight distinctly influenced the extraction of volatiles for each fiber. PDMS/DVB was the most efficient, followed by PA and CAR/PDMS/DVB. Thirty-eight compounds that comprise the aroma were identified among sesquiterpenes (56.4\%) and monoterpenes (30.8\%), such as $\alpha$-fenchene, guaiol, globulol, $\alpha$-muurolene, $\gamma$-himachalene, $\alpha$-pinene, $\gamma$-elemene, and patchoulene.

Keywords: Myrtaceae; headspace solid-phase microextraction; Cerrado; aroma; volatile organic compounds

\section{Introduction}

Cerrado is an ecosystem that concentrates one of the greatest biodiversities on the planet, occupying about $22 \%$ of the Brazilian territory and typified by a variety of plant species such as herbs, sub-shrubs, shrubs, trees, and vines, which together add up to more than 6000 identified species [1]. It is formed by different ecoregions due to its great latitudinal and longitudinal variation, comprising open pastures, savanna woods, forests, and perennial riparian forests [2]. Fruit trees stand out mainly due to their economic potential and the high nutrient content that they present in their compositions, in addition to the distinct flavor and aroma characteristics of their fruits [3].

Cerrado fruits such as araticum [4], grumixama [5,6], acerola [7], cagaita [8], murici [9,10], and pequi $[11,12]$ have stood out commercially due to their unique nutritional properties, 
flavors, and aromas. The expansion of cultivation and advances in research on these fruits have fostered the development of new products for the food industry, providing income generation to communities of small producers and fruit collectors in the Cerrado [13-15].

Eugenia klotzschiana O. Berg belongs to the Myrtaceae family and has important nutritional value, including the content of polyphenolic compounds (566.3 mg Gallic Acid Equivalent $100 \mathrm{~g} \mathrm{~g}^{-1}$ ) and flavonoids (550.0 mg Quercetin Equivalent/100 g), in addition to a considerable content of ascorbic acid (8.66 mg $100 \mathrm{~g}^{-1}$ fresh weight) and dietary

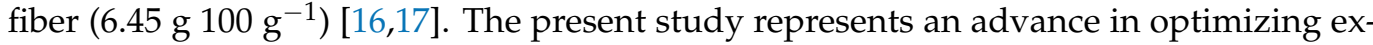
traction conditions of volatile compounds from the fruits of Eugenia klotzschiana by the solid-phase microextraction (SPME) method. It is the first time that the influence of the fibers PA, DVB/CAR/PDMS, and PDMS/DVB, as well as temperature, time, and agitation employed in the extraction of VOCs present in these fruits were evaluated. In a previous study, one experimental condition used PDMS/DVB SPME fiber, allowing isolation of only 11 compounds [18].

Volatile compounds constitute the aroma of fruits, which is understood as the process of releasing low molecular weight compounds that impart odors and are captured by the human sensory system through olfaction [19]. It is noteworthy that the fruit aroma associated with the characteristics of color, texture, and size is fundamental in the perception and subsequent predilection of the consumer to a particular food. Furthermore, volatile compounds can be used to differentiate varieties of the same plant species [9], as important chemical signals in the cultivation and maintenance of the species in nature [20], and also allow the characterization of the fruit maturation stages and its quality as a whole [21].

Analysis of volatile compounds covers the process of extraction or recovery, desorption, separation, detection, and identification. Several extraction methods have been developed. Currently, headspace (HS) solid-phase microextraction (SPME) (HS-SPME) is used for the analysis of samples with complex matrices, such as food, due to the excellent results obtained and no employment of organic solvents or destruction of the analyzed sample. In addition to its repeatability and possibility to adjust the conditions and types of fibers used. Fibers available on the market vary in the type of coating and the thickness. Coatings represent the phase that establishes affinity for the analytes in the HS-SPME system, allowing their extraction, such as divinylbenzene/carboxen/polydimethylsiloxane (DVB/CAR/PDMS), polydimethylsiloxane/divinylbenzene (PDMS/DVB), and polyacrylate (PA). Desorption, separation, and detection steps can be performed using gas chromatography coupled with mass spectrometry (GC-MS) or high-performance liquid chromatography (HPLC) [9,22-24].

Therefore, the objective of this work was to study the optimal conditions for extraction, detection, and determination of volatiles from the pulp of Eugenia klotzschiana O. Berg fruits, as well as to define the best SPME fiber and discriminate the volatile chemical constituents employing HS-SPME and GC-MS.

\section{Results and Discussion}

Major components of the aroma found in the pulp of Eugenia klotzschiana are sesquiterpenes $(55.3 \%)$ and monoterpenes $(31.6 \%)$. Esters, amines, and other compounds are present in smaller amounts (13.2\%) (Figure 1). It is noteworthy that the volatile chemical composition is characteristic of each fruit due to the characteristics of the food matrix and the influence of external factors, such as environmental and cultivation conditions, to which the plant species was exposed [25].

In acerola, for example, volatiles are mainly made up of esters and alcohols [7], whereas for cambuí, sesquiterpenes correspond to $71 \%$ of the identified volatiles [9]. A study with cagaita (Eugenia dysenterica) showed monoterpenes representing $34.6 \%$ of the volatile profile and esters, 36.3\% [26]. In contrast, grumixama (Eugenia brasiliensis) comprised $94.7 \%$ sesquiterpenes and $5.3 \%$ monoterpenes [5]. 


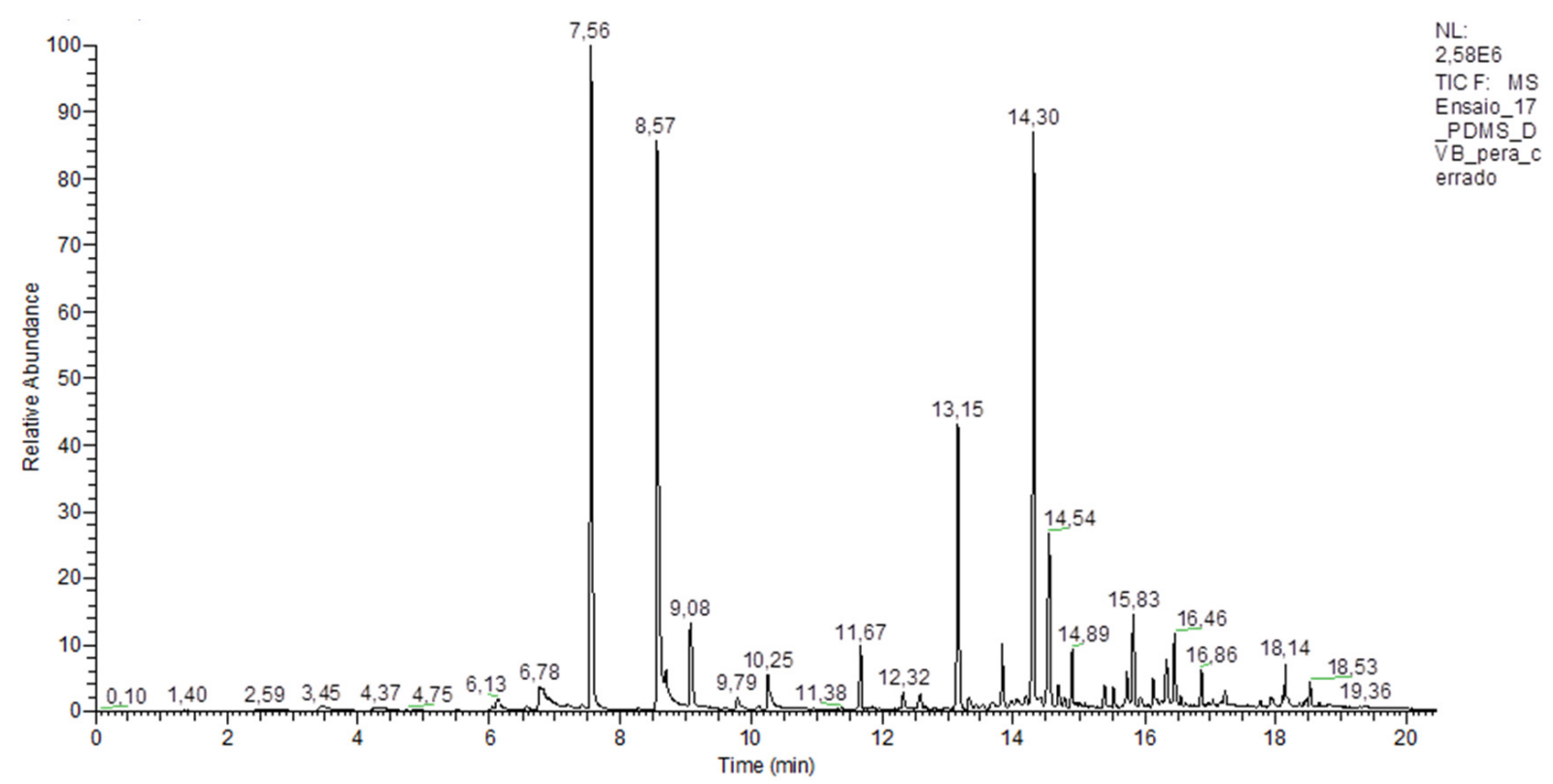

Figure 1. Peaks detected by GC-MS represent volatile compounds extracted by the PDMS/DVB fiber.

Thirty-eight volatile compounds were identified by employing three extraction fibers. Table A1 (Appendix A) shows the breakdown of volatile chemical constituents detected in the fruit pulp. The arranged columns represent identified compounds and the respective type(s) of fiber(s) that extracted them. The letter " $X$ " marks the fiber that extracted the compound for identification purposes.

What is sensorially perceived as the aroma is the set of synergistic effects of volatile compounds present in fruits. The composition of the compounds becomes specific to each species $[10,26]$. However, it is possible to identify similar compounds in E. klotzschiana and cambuí, which have eight common volatiles in the aromatic profile: $\alpha$-fenchene, guaiol, globulol, $\alpha$-muurolene, $\gamma$-himachalene, $\alpha$-pinene, $\gamma$-elemene, and patchoulene [27].

$\alpha$-Pinene confers a characteristic odor of pine [28], also characteristic of the presence of camphene, which emits a woody and citrusy odor [29]. Myrtenol contributes to the odor of flowers and mint, while isogeraniol contributes to flowers and jasmine [30]. Linalyl acetate is responsible for the fruit and lavender notes, softening the fennel and lavanduol, the green lavender aroma [31]. $\alpha$-Humulene is present in high amounts in hops (Humulus lupulus), which is used in beer production due to its flavoring potential. It provides a characteristic aroma to the beverage and other compounds and woody notes [29]. It is noteworthy that E. klotzschiana is consumed by the regional population in juices and is known as cervejinha do campo, "field beer", due to the characteristic aroma of the fruit. Finally, guaiene and benzyl acetate contribute to the perception of wood and balsamic, apple, floral, and fruity notes, respectively [32].

Figure 2 shows the percentage of the area of volatiles extracted from the chromatograms using each SPME fiber. The largest volatile areas were detected in the chromatograms of the tests performed with PDMS/DVB fiber, followed by PA fiber and with the smallest area, DVB/CAR/PDMS fiber, corresponding to $73.4 \%, 15.9 \%$ and $10.7 \%$ of the entire identified area, respectively.

A possible interpretation of the fibers' behavior due to the volatiles present in the pulp of E. klotzschiana is the affinity of the type of coating of each fiber for specific analytes since the aromatic profile of E. klotzschiana is mainly composed of sesquiterpenes $(56.41 \%)$, which are compounds characterized by medium polarity. The PDMS/DVB coating is semipolar, making it chemically more susceptible to adsorb substances with similar polarity [10]. While esters, which have higher polarity, represent less than $13.60 \%$ of the volatiles, corroborating the values of the area extracted by the fiber with the polyacrylate coating. 


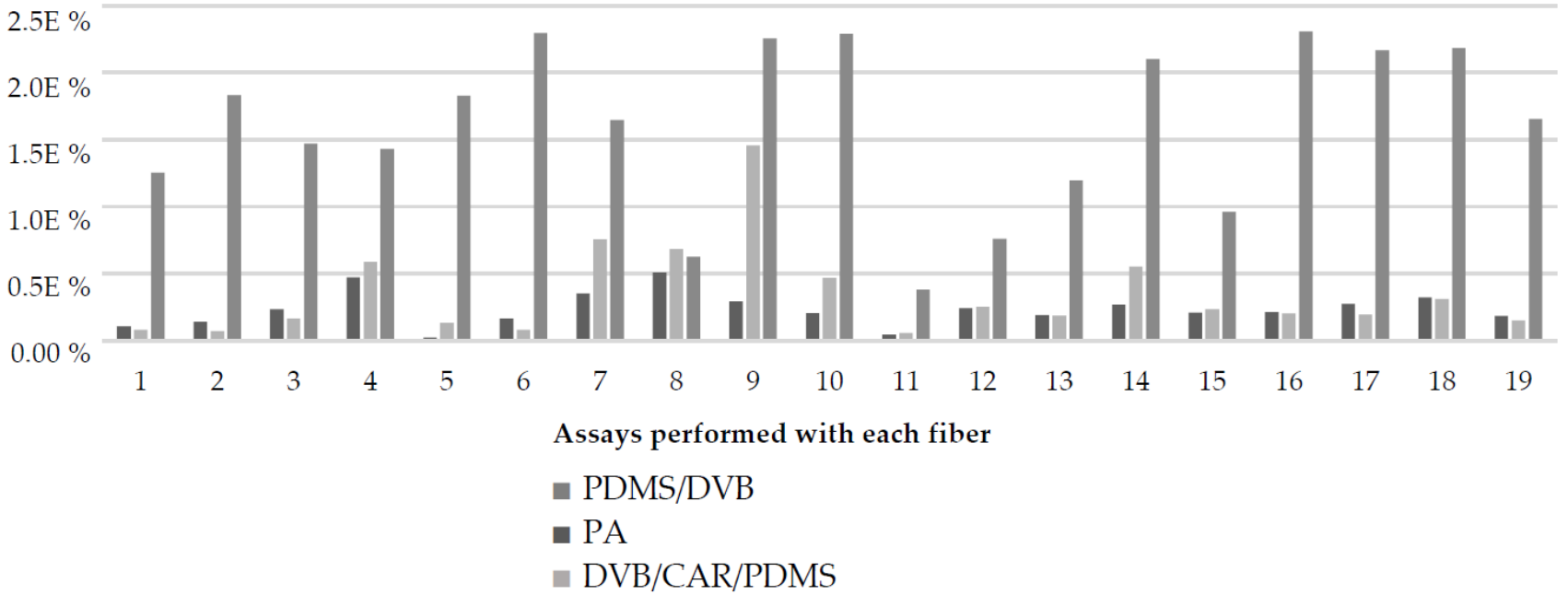

Figure 2. Percentage of peak areas of volatile chemical compounds extracted by SPME-HS using different types of coating.

The DVB/CAR/PDMS fiber had the smallest area extracted from volatiles. However, five compounds were only isolated in assays carried out with this coating: cadina-3,9-diene, $( \pm)$ - $\alpha$-pinene, $\gamma$-himachalene, $( \pm)$-camphene, and sabinene hydrate trans acetate.

\subsection{Evaluation of the Effect of Independent Variables on the Extraction of VOCs}

\subsubsection{Extraction Temperature}

Temperature is one of the main factors influencing the yield of volatile compounds extraction, especially in plant matrices $[7,9,26]$. This condition is due to its ability to maximize or reduce the extracted volatiles due to the potential degradation of analytes that exacerbated temperature values can trigger [33]. For the levels used in this study, the temperature significantly affected the experiment performed with DVB/CAR/PDMS and PDMS/DVB fibers.

As for DVB/CAR/PDMS fibers, the temperature was the only variable that exerted a significant effect, maximizing the area of extracted volatiles (Figure 3). It was observed that the largest extraction areas were obtained at temperatures from $80^{\circ} \mathrm{C}$. Related to the region with the most significant area, the use of larger amounts of pulp is noted, indicating that, in order to obtain significant values for the volatile area, it is necessary to use high temperatures and a larger quantity of pulp. A possible explanation is the lower affinity of the compounds with the fiber coating, making it demand high values of the system variables to obtain a better response [22].

Observing the graph of the response surface of the PDMS/DVB fiber (Figure 3), which depicts the behavior of temperature in the extraction of volatiles, it appears that temperature had a positive effect on the area of extracted volatiles. Thus, the response was maximized in the presence of heat, especially from 50 to $107^{\circ} \mathrm{C}$, where the region of the response surface was identified with a larger area. However, temperatures higher than $107^{\circ} \mathrm{C}$ reduced the volatile area, indicating that although it is effective and important for the HS-SPME system in the analyzed sample, exacerbating values can negatively affect volatile extraction. A possible explanation for this is the occurrence of degradation of volatiles due to the use of high temperatures [33], which in the studied system was temperatures higher than $107^{\circ} \mathrm{C}$. From $50^{\circ} \mathrm{C}$, a positive effect on the extraction yield is already observed, indicating that applying high temperatures is unnecessary. 


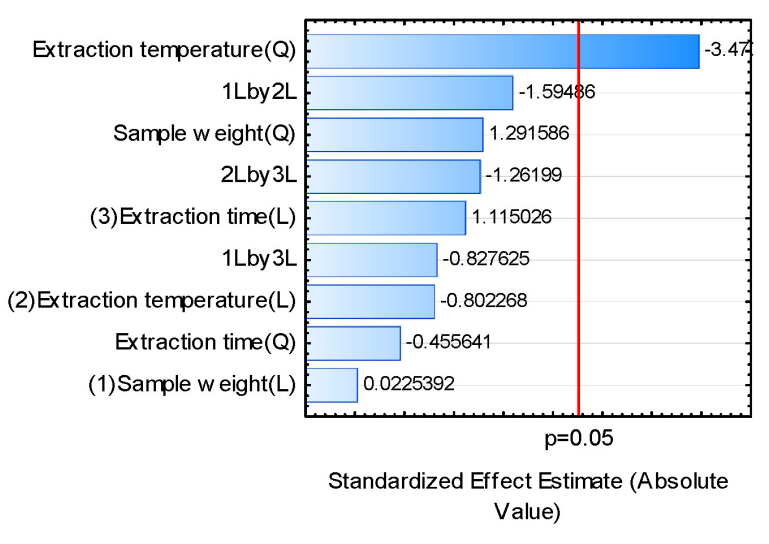

(a)

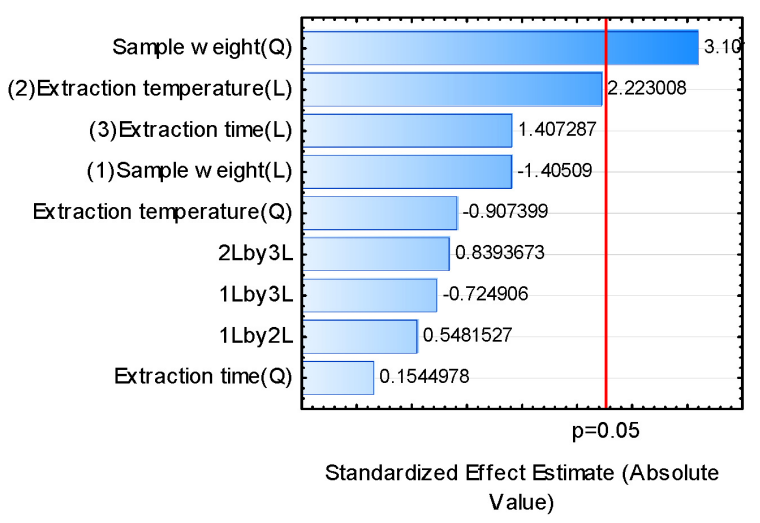

(b)

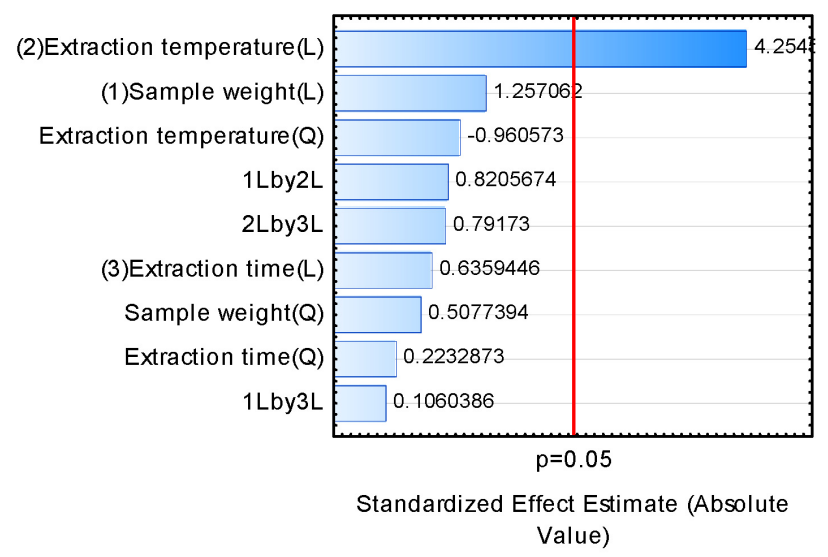

(c)

Figure 3. Effects of time and temperature of extraction and quantity of pulp variables on the extraction of volatiles using different fiber coatings for HS-SPME: (a) PDMS/DVB, (b) PA, and (c) CAR/PDMS/DVB.

In assays carried out with PA fibers, the temperature conditions had no significant effect on the extraction of volatiles. The lowest temperature values were enough to release analytes from the plant matrix and their adsorption by compatibility with the polyacrylate coating from the headspace. This reinforces that it is not necessary to use high-temperature values to maximize the yield of volatile extraction from E. klotzschiana in the studied systems.

\subsubsection{Extraction Time}

Extraction time is an essential parameter for the effective use of the HS-SPME technique. It must be sufficient to release the analytes from the analyzed matrix until they settle in equilibrium in the headspace vial and are adsorbed or absorbed by the fiber coating $[23,33,34]$. In the experiments carried out, ranging from 10 to $30 \mathrm{~min}$, the time did not significantly affect the volatile extraction yield for the studied fibers.

Observing the DVB/CAR/PDMS fiber response surface graph (Figure 4), it is possible to confirm no influence of weather conditions on the extracted volatile area. The most significant areas were obtained from $24 \mathrm{~min}$ of fiber exposure. It was observed that there was no increase in the efficiency of extracting volatile compounds from the sample, even in tests with more extended time values at a constant sample quantity. 
On the other hand, the volatile areas extracted by PDMS/DVB were greater when using time values greater than $20 \mathrm{~min}$, even when associated with a smaller amount of sample, and intrinsically, a lower concentration of VOCs. In regions with sample amounts greater than $2.0 \mathrm{~g}$, it is also possible to obtain higher extraction yields. However, they were not superior to those obtained with $0.5 \mathrm{~g}$ of E. klotzschiana pulp at a time longer than $20 \mathrm{~min}$. The optimal extraction time calculated by the model was $19.71 \mathrm{~min}$, confirming what was demonstrated by the response surface.

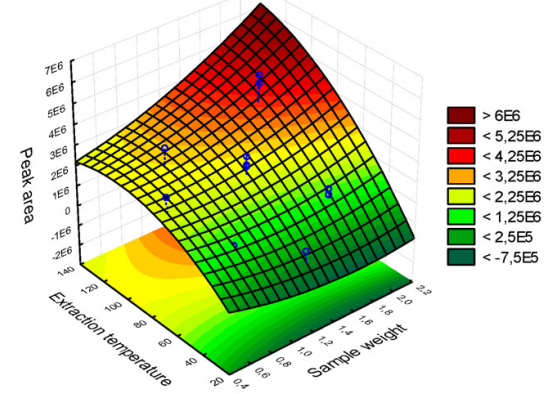

(a)

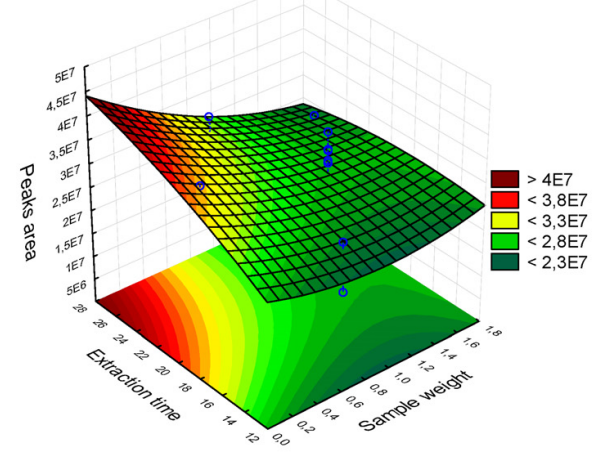

(c)

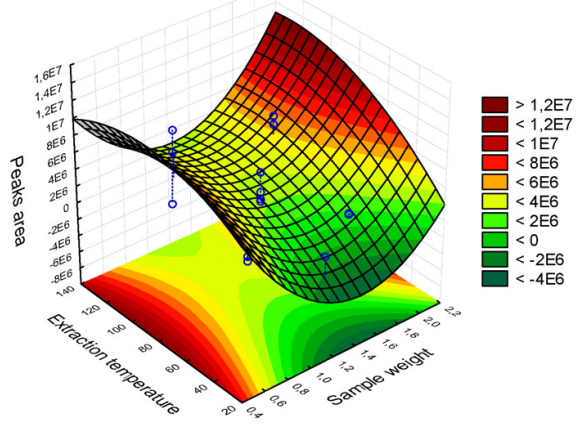

(e)

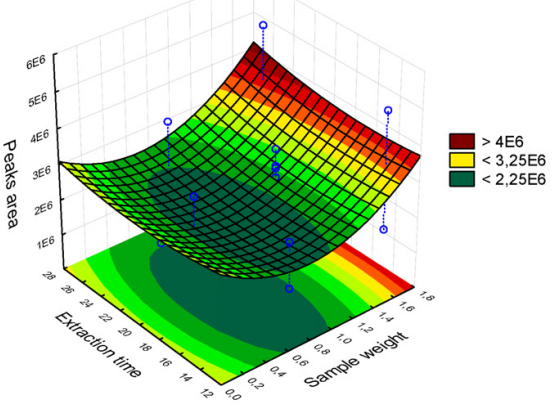

(b)

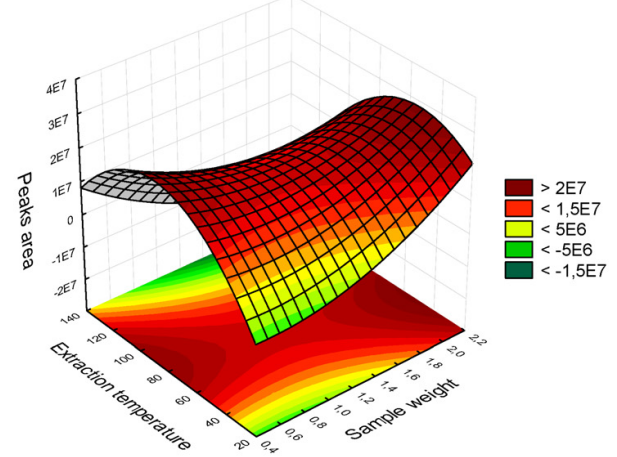

(d)

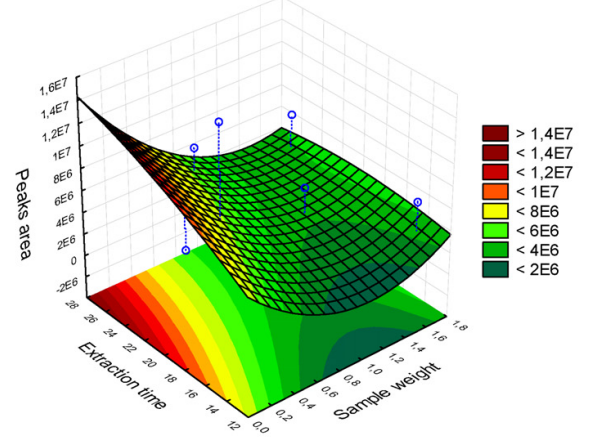

(f)

Figure 4. Three-dimensional response surface (RSM) graphs of the variables time and temperature of extraction and amount of pulp in the extraction of volatiles using different fiber coatings for HS-SPME: (a) DVB/CAR/PDMS extraction temperature vs. sample weight, (b) DVB/CAR/PDMS extraction time vs. sample weight, (c) PDMS/DVB extraction time vs. sample weight, (d) PDMS/DVB extraction temperature vs. sample weight, (e) PA extraction temperature vs. sample weight, and (f) PA extraction time vs. sample weight. 
As for the PA fiber, it was observed that the highest extraction yield values were detected in a time greater than $20 \mathrm{~min}$. However, similar values were not observed when larger amounts of sample were used, as occurred in the PDMS/DVB fiber. A possible explanation is that the fiber sorbent reached its maximum adsorption capacity of the analytes to which it was exposed [35].

\subsubsection{Sample Weight}

Sample weight in the experiments ranged from 0.5 to $2.0 \mathrm{~g}$ of E. klotzschiana pulp. The volume contained in the headspace flask must be sufficient for the isolation of volatiles and their adsorption and/or absorption by the sorbent to occur [9].

It was found that sample weight did not influence volatile extraction yield when using DVB/CAR/PDMS and PDMS/DVB fibers. However, it is noteworthy that, due to the larger sample volume, it was possible to detect an increase in yield in PDMS/DVB assays that used more than $2.0 \mathrm{~g}$ of pulp with extraction times shorter than $16 \mathrm{~min}$. This result portrays that a greater quantity of analytes were eluted into the vapor phase (headspace) due to the more significant amount of pulp, and the fiber could adsorb this greater fraction, maximizing the extracted area.

When analyzing results with DVB/CAR/PDMS fibers, the most considerable areas were obtained only from $1.4 \mathrm{~g}$ of pulp, regardless of the temperature or time employed.

As for PA fibers, the variation in pulp amount positively affected the yield of extraction of volatiles, increasing the area extracted when the amount of pulp was more significant than $2.0 \mathrm{~g}$. However, it is essential to emphasize that $0.5 \mathrm{~g}$ was enough to obtain the same volatile areas. What happens when using $2.0 \mathrm{~g}$ of pulp or more is the greater accumulation of analytes in the headspace due to the more significant amount of substrate, so that the content was able to be absorbed by the polyacrylate sorbent, for the volatiles present in the pulp of E. klotzschiana at the levels and parameters studied [34].

\section{Materials and Methods}

\subsection{Sample Acquisition}

Fruit samples of Eugenia klotzschiana O. Berg were obtained through a donation from trees located in the region of Turmalina, State of Minas Gerais, Brazil (Lat-17.287410, Long42.718210). Fully ripened fruits (greenish-yellow skin color) were collected directly from trees from January to February 2019, amounting to about $3 \mathrm{~kg}$.

After collection, the fruits were washed under running water to remove impurities and sanitized with a chlorinated solution (200 ppm) for $15 \mathrm{~min}$, followed by rinsing in running water. The fruits were then fully packed in polyethylene bags and stored at a temperature of $-18{ }^{\circ} \mathrm{C}$ until analysis. Samples were transported in a secondary package containing ice to the Mass Spectrometry Laboratory of the Department of Chemistry at the Federal University of Minas Gerais (UFMG), Belo Horizonte, Minas Gerais, Brazil.

Analyses were performed using the fruit pulp, obtained by manual pulp removal, followed by homogenization with a mixer (Mixer Mondial Versatile Black M-08).

\subsection{Experimental Design}

The central composite design was used with five repetitions at the central point and six axial points, with three independent variables: extraction time (minutes), extraction temperature (Celsius), and sample weight (grams), with two levels each, namely: for extraction time a minimum level of $10 \mathrm{~min}$, a maximum of $30 \mathrm{~min}$, and a center point of $20 \mathrm{~min}$, for extraction temperature a minimum of $30^{\circ} \mathrm{C}$, a maximum of $120^{\circ} \mathrm{C}$, and a center point of $75^{\circ} \mathrm{C}$, and for sample weight a minimum of $0.5 \mathrm{~g}$, a maximum of $2.0 \mathrm{~g}$, and a center point of $1.25 \mathrm{~g}$.

Three types of fibers were used, DVB/CAR/PDMS $(50 / 30 \mu \mathrm{m})$, PDMS/DVB $(65 \mu \mathrm{m})$, and PA $(85 \mu \mathrm{m})$ (Sigma-Aldrich, St. Louis, MO, USA) [24]; thus, three experiments were performed with nineteen repetitions each. 
Peaks included were those with a relative abundance greater than $2 \%$ of the total area of the chromatogram. The total relative area (\%) of the peaks: the sum of the percentage abundance of the area of valid peaks obtained in the chromatograms, was determined as the dependent variable using Microsoft Office Excel ${ }^{\circledR}$ 2010. Results were analyzed according to the area extracted by each fiber and the behavior of the independent variables through the response surface methodology using Statisticv.10 (Stat-Soft Inc., Tulsa, OK, USA).

\subsection{Headspace Solid-Phase Microextraction (HS-SPME)}

Eugenia klotzschiana O. Berg pulp was transferred to identified glass vials. Pulp amount was weighed according to the experimental planning, and the flasks were sealed with an aluminum seal and septum rubber $[7,10]$.

Subsequently, the vials containing the pulp were subjected to time, temperature, fiber type, and extraction conditions. For this purpose, a system was structured containing a heating plate, an aluminum block to contain the vials with the sample, and an iron support with a clamp to ensure the proper positioning of the SPME device containing the fiber when exposed. After extraction, the fiber was retracted and taken to the chromatograph (GC-MS) for desorption of the compound [9,23,34,36].

\subsection{Gas Chromatography Coupled with Mass Spectrometry Analysis and Identification of Volatile Compounds}

Volatile compounds were analyzed using a gas chromatograph (Trace CG Ultra) coupled to the mass spectrometer (Polaris Q) with an ion-trap analyzer (Thermo Scientific, San Jose, CA, USA). Compounds were separated using a capillary column HP-5 MS (5\% phenyl and 95\% methylpolysiloxane) of $30 \mathrm{~m}$ long, $0.25 \mathrm{~mm}$ internal diameter, $0.25 \mu \mathrm{m}$ film thickness, and helium gas with a constant flow rate of $1 \mathrm{~mL} \mathrm{~min}^{-1}$ (Agilent Techonolgies Inc., Waldbronn, Germany). The injector (splitless mode) was maintained for 5 min at a temperature of $250{ }^{\circ} \mathrm{C}$, the ion source at $200{ }^{\circ} \mathrm{C}$, and the interface at $270{ }^{\circ} \mathrm{C}$. The oven was programmed at $40{ }^{\circ} \mathrm{C}$ for $1 \mathrm{~min}$, followed by an increase in temperature at a rate of $12{ }^{\circ} \mathrm{C}$ $\mathrm{min}^{-1}$ until it reached $120^{\circ} \mathrm{C}$, maintaining it for $2 \mathrm{~min}$. Then, at $15^{\circ} \mathrm{C} \mathrm{min}^{-1}$ to $150{ }^{\circ} \mathrm{C}$ and finally, at $20^{\circ} \mathrm{C} \mathrm{min}^{-1}$ to $245^{\circ} \mathrm{C}$, maintaining for $2 \mathrm{~min}$.

The identification of volatile compounds was carried out using the National Institute of Standards and Technology Research Library (NIST). This identification was also based on articles that determined volatile compounds in Eugenia klotzschiana O. Berg. The total peak area was obtained in Xcalibur1.4 from Thermo Electron Corporation (Thermo Electron, San Jose, CA, USA) and analyzed in Microsoft Office Excel $2010^{\circledR}$.

\section{Conclusions}

The profile of volatile compounds from the pulp of Eugenia klotzschiana O. Berg is varied and complex, containing 38 volatiles constituted by $55.3 \%$ of sesquiterpenes and $31.6 \%$ of monoterpenes. The PDMS/DVB fiber allowed the identification of 23 volatiles, the PA fiber 17, and the DVB/CAR/PDMS fiber only 8. Variables of time, temperature, and weight of the sample behaved differently for the three fibers studied. However, the HS-SPME method proved to be effective in extracting volatile compounds present in the pulp of Eugenia klotzschiana O. Berg, with the best performance occurring when using the PDMS/DVB fiber, under conditions of $56^{\circ} \mathrm{C}, 2.6 \mathrm{~g}$ of pulp, and 20 min of extraction. Consequently, this study presented new information about a fruit species of great importance in the Cerrado.

Author Contributions: Conceptualization, J.O.F.M., A.P.X.M., R.L.B.d.A., Y.M.G., and R.A.; methodology, R.L.B.d.A., J.O.F.M., A.P.X.M., R.A., and M.R.S.; software, Y.M.G., A.H.d.O.J., and A.L.C.C.R.; validation, A.L.C.C.R., M.R.S., and A.H.d.O.J.; formal analysis, A.P.X.M., M.R.S., and A.L.C.C.R.; investigation, A.P.X.M.; resources, R.L.B.d.A., R.A., A.C.C.F.F.d.P., and J.O.F.M.; data curation, A.P.X.M. and R.L.B.d.A.; writing—original draft preparation, A.P.X.M.; writing—review and editing, A.P.X.M., A.H.d.O.J., and A.L.C.C.R.; visualization, R.L.B.d.A., and A.C.C.F.F.d.P.; supervision, R.L.B.d.A. and J.O.F.M.; project administration, J.O.F.M. and A.P.X.M.; funding acquisition, R.A., J.O.F.M., A.P.X.M., 
R.L.B.d.A., and A.C.C.F.F.d.P. All authors have read and agreed to the published version of the manuscript.

Funding: This research was funded by CAPES, CNPq (304051/2018), FAPEMIG, IFMG, UFMG, and UFSJ, to whom the authors would like to extend their gratitude. This research is developed within the framework of the Sustainable Rural Project - Cerrado, funded by Technical Cooperation approved by the Inter-American Development Bank (IDB), with resources from the UK Government's International Climate Finance, with the Ministry of Agriculture, Livestock, and Supply (MAPA) as the institutional beneficiary. The Brazilian Institute for Development and Sustainability (IABS-08026000510/2003-51) is responsible for the project's execution and administration, and the ILPF Network Association, through Embrapa, is responsible for the scientific coordination and technical support.

Institutional Review Board Statement: Not applicable.

Informed Consent Statement: Not applicable.

Data Availability Statement: All data are contained within the article.

Acknowledgments: The authors would like to thank the Universidade Federal de Minas Gerais (UFMG), Instituto Federal de Educação Ciência e Tecnologia de Minas Gerais (IFMG), and Universidade Federal de São João del-Rei (UFSJ) for the infrastructure to carry out the analyses and for the financial support. The authors also thank CAPES, CNPq, Pró-Reitoria de Pesquisa - PRPq - FMG, and FAPEMIG for the financial support.

Conflicts of Interest: The authors declare no conflict of interest.

Sample Availability: Samples of Eugenia klotzschiana O. Berg are available from the authors. 


\section{Appendix A}

Table A1. Volatile organic compounds identified by three different types of SPME fibers and GC-MS in the pulp of Eugenia klotzschiana O. Berg.

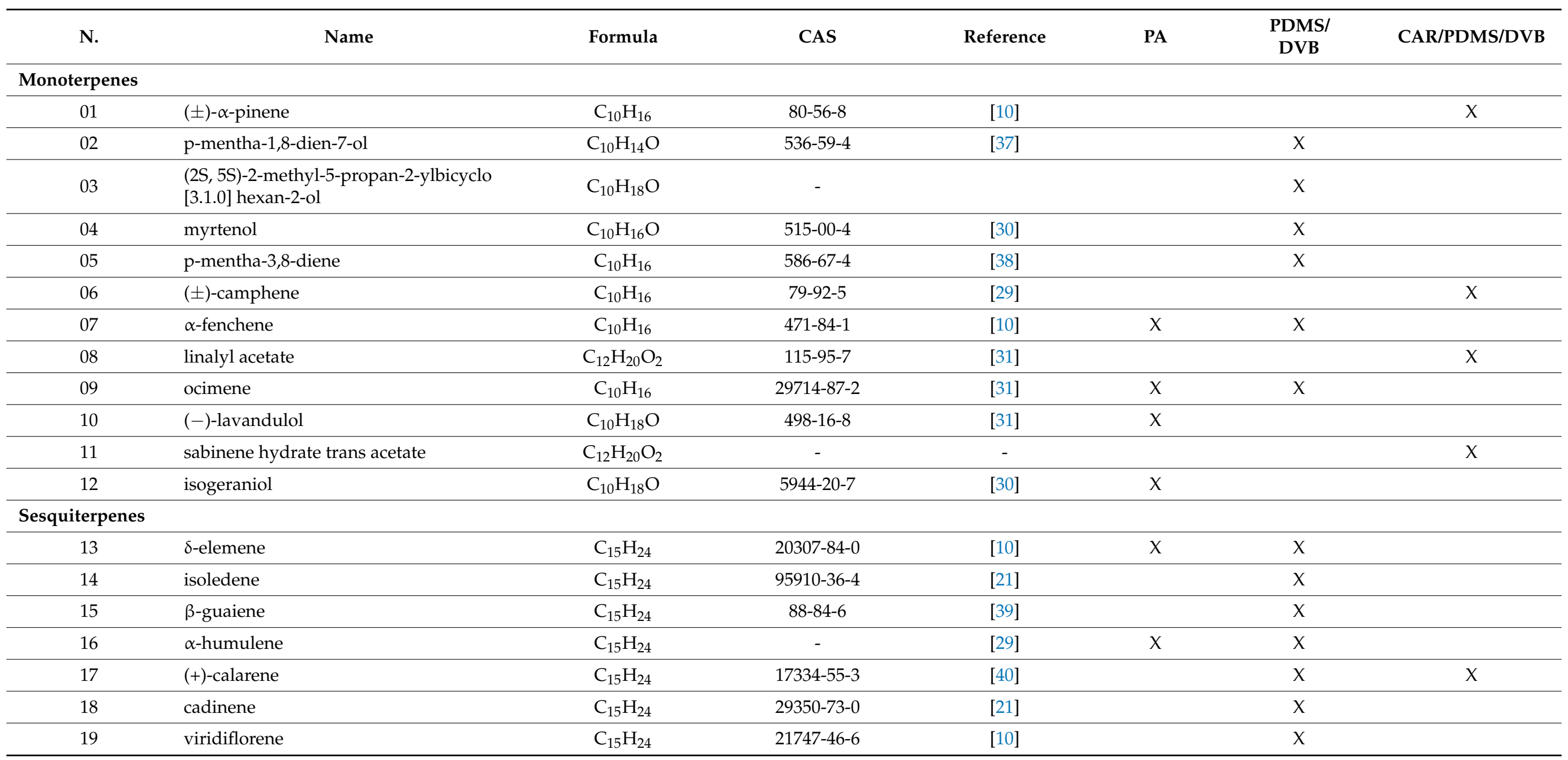


Table A1. Cont.

\begin{tabular}{|c|c|c|c|c|c|c|c|}
\hline $\mathbf{N}$. & Name & Formula & CAS & Reference & PA & $\begin{array}{l}\text { PDMS/ } \\
\text { DVB }\end{array}$ & CAR/PDMS/DVB \\
\hline 20 & $\alpha$-guaiene & $\mathrm{C}_{15} \mathrm{H}_{24}$ & $3691-12-1$ & [10] & $x$ & $x$ & \\
\hline 21 & $\gamma$-himachalene & $\mathrm{C}_{15} \mathrm{H}_{24}$ & $53111-25-4$ & [10] & & & $x$ \\
\hline 22 & $(-)-\gamma$-muurolene & $\mathrm{C}_{15} \mathrm{H}_{24}$ & $24268-39-1$ & [10] & $x$ & $x$ & \\
\hline 23 & acoradiene & $\mathrm{C}_{15} \mathrm{H}_{24}$ & $24048-44-0$ & [41] & $x$ & $x$ & \\
\hline 24 & (+)-cyclosativene & $\mathrm{C}_{15} \mathrm{H}_{24}$ & $22469-52-9$ & [21] & $x$ & $x$ & \\
\hline 26 & cadina-3,9-diene & $\mathrm{C}_{15} \mathrm{H}_{24}$ & $523-47-7$ & [42] & & & $x$ \\
\hline 27 & globulol & $\mathrm{C}_{15} \mathrm{H}_{26} \mathrm{O}$ & $489-41-8$ & [10] & $x$ & $x$ & \\
\hline 28 & patchoulene & $\mathrm{C}_{15} \mathrm{H}_{24}$ & - & [10] & $x$ & & \\
\hline 29 & $\alpha$-caryophyllene alcohol & $\mathrm{C}_{15} \mathrm{H}_{2} 6 \mathrm{O}$ & $4586-22-5$ & [43] & $x$ & & \\
\hline 30 & (-)-guaiol & $\mathrm{C}_{15} \mathrm{H}_{26} \mathrm{O}$ & $489-86-1$ & [10] & $x$ & & \\
\hline 31 & cedryl acetate & $\mathrm{C}_{17} \mathrm{H}_{28} \mathrm{O}_{2}$ & $77-54-3$ & {$[44]$} & $x$ & & \\
\hline 33 & $\begin{array}{l}\text { spiro [4.5]decan-7-one, } \\
\text { 1,8-dimethyl-8,9-epoxi-4-isopropyl }\end{array}$ & $\mathrm{C}_{15} \mathrm{H}_{24} \mathrm{O}_{2}$ & $61050-91-7$ & [20] & & $x$ & \\
\hline Other & & & & & & & \\
\hline 34 & N-(2-hydroxipropyl) ethylenediamine & $\mathrm{C}_{15} \mathrm{H}_{14} \mathrm{~N}_{2} \mathrm{O}$ & $123-84-2$ & - & & $x$ & \\
\hline 35 & ethyl hexanoate & $\mathrm{C}_{8} \mathrm{H}_{16} \mathrm{O}_{2}$ & $123-66-0$ & {$[45]$} & & $x$ & \\
\hline 36 & benzyl alcohol & $\mathrm{C}_{7} \mathrm{H}_{8} \mathrm{O}$ & $100-51-6$ & [45] & $x$ & & \\
\hline 37 & benzyl acetate & $\mathrm{C}_{9} \mathrm{H}_{10} \mathrm{O}_{2}$ & $140-11-4$ & [46] & $x$ & $x$ & $x$ \\
\hline 38 & (E)-3,7-dimetlnon-6-enal & $\mathrm{C}_{11} \mathrm{H}_{20} \mathrm{O}$ & - & - & & $x$ & \\
\hline & \multicolumn{4}{|c|}{ Total compounds identified by each fiber } & 18 & 23 & 08 \\
\hline
\end{tabular}




\section{References}

1. Junqueira, N.T.V.; Junqueira, K.P.; Pereira, A.; Pereira, E.; Braga, M.; Conceição, L.D.; Faleiro, F. Frutíferas nativas do cerrado: O extrativismo e a busca da domesticação. In Proceedings of the Embrapa Cerrados-Artigo em Anais de Congresso (ALICE), Congresso Brasileiro de Fruticultura, Bento Gonçalves, Brazil, 22-26 October 2012.

2. Sano, E.E.; Bettiol, G.M.; Martins, E.D.S.; Couto Júnior, A.F.; Vasconcelos, V.; Bolfe, E.L.; Victoria, D.D.C. Características gerais da paisagem do Cerrado. In Embrapa Informática Agropecuária-Capítulo em livro científico (ALICE); Embrapa: Brasília, Brazil, 2020.

3. Vieira, R.F.; Agostini-Costa, T.; Silva, D.B.; Ferreira, F.R.; Sano, S.M. Frutas Nativas da Região Centro-Oeste do Brasil; Embrapa Recursos Genéticos e Biotecnologia: Brasília, Brasil, 2006.

4. Arruda, H.S.; Pereira, G.A.; de Morais, D.R.; Eberlin, M.N.; Pastore, G.M. Determination of free, esterified, glycosylated and insoluble-bound phenolics composition in the edible part of araticum fruit (Annona crassiflora Mart.) and its by-products by HPLC-ESI-MS/MS. Food Chem. 2018, 245, 738-749. [CrossRef] [PubMed]

5. Ramos, A.L.C.C.; Mendes, D.D.; Silva, M.R.; Augusti, R.; Melo, J.O.F.; de Araújo, R.L.B.; Lacerda, I.C.A. Chemical profile of Eugenia brasiliensis (Grumixama) pulp by PS/MS paper spray and SPME-GC/MS solid-phase microextraction. Res. Soc. Dev. 2020, 9, e318974008. [CrossRef]

6. Teixeira, L.D.L.; Bertoldi, F.C.; Lajolo, F.M.; Hassimotto, N.M.A. Identification of ellagitannins and flavonoids from Eugenia brasilienses Lam. (Grumixama) by HPLC-ESI-MS/MS. J. Agric. Food Chem. 2015, 63, 5417-5427. [CrossRef]

7. García, Y.M.; Rufini, J.; Campos, M.P.; Guedes, M.N.; Augusti, R.; Melo, J.O. SPME fiber evaluation for volatile organic compounds extraction from acerola. J. Braz. Chem. Soc. 2019, 30, 247-255. [CrossRef]

8. Silva, M.R.; De Souza, A.G.; De Araújo, R.L.B.; Lacerda, I.C.A.; Augusti, R.; Melo, J.O.F.; Mendonça, H.D.O.P. Análise metabolômica de cagaitas utilizando a espectrometria de massas com ionização por paper spray. Avanços Ciência E Tecnol. Alimentos. Científica 2020, 1, 25-41. [CrossRef]

9. García, Y.M.; Ramos, A.L.C.C.; de Paula, A.C.C.F.F.; do Nascimento, M.H.; Augusti, R.; de Araújo, R.L.B.; Melo, J.O.F. Chemical Physical Characterization and Profile of Fruit Volatile Compounds from Different Accesses of Myrciaria floribunda (H. West Ex Wild.) O. Berg through Polyacrylate Fiber. Molecules 2021, 26, 5281. [CrossRef]

10. García, Y.M.; Ramos, A.L.C.C.; de Oliveira Júnior, A.H.; de Paula, A.C.C.F.F.; de Melo, A.C.; Andrino, M.A.; Melo, J.O.F. Physicochemical Characterization and Paper Spray Mass Spectrometry Analysis of Myrciaria Floribunda (H. West ex Willd.) O. Berg Accessions. Molecules 2021, 26, 7206. [CrossRef]

11. Bess, J.; Araújo, S.S.; Grellmann, B.P.; Cruz, D.C.; Alamino, M.; Melo, J.O.F.; Reina, L.D.C.B. Biometric and physical-chemical analysis of pequis collected in the state of Mato Grosso. Sci. Electron. Arch. 2020, 13, 24-30. [CrossRef]

12. Santos, B.O.; Augusti, R.; Melo, J.O.F.; Takahashi, J.A.; de Araújo, R.L.B. Optimization of extraction conditions of volatile compounds from pequi peel (Caryocar brasiliense Camb.) using HS-SPME. Res. Soc. Dev. 2020, 9, e919974893. [CrossRef]

13. Ramos, S.A.; Silva, M.R.; Jacobino, A.R.; Damasceno, I.A.N.; Rodrigues, S.M.; Carlos, G.A.; Capobiango, M. Caracterização físico-química, microbiológica e da atividade antioxidante de farinhas de casca e amêndoa de manga (Mangifera indica) e sua aplicação em brownie. Res. Soc. Dev. 2021, 10, e22310212436. [CrossRef]

14. Figueiredo, Y.G.; Bueno, F.C.; Júnior, A.H.D.O.; Mazzinghy, A.C.D.C.; Mendonça, H.D.O.P.; de Oliveira, A.F.; De Melo, A.C.; Reina, L.D.C.B.; Augusti, R.; Melo, J.O.F. Profile of the volatile organic compounds of pink pepper and black pepper. Sci. Electron. Arch. 2021, 14. [CrossRef]

15. Silva, M.R.; Freitas, L.G.; Mendonça, H.D.O.; Souza, A.G.; Pereira, H.V.; Augusti, R.; Melo, J.O.F.; Araújo, R.L. determination of chemical profile of Eugenia dysenterica ice cream using PS-MS and HS-SPME/GC-MS. Química Nova 2021, 44, 129-136. [CrossRef]

16. Carneiro, N.S. Caracterização Química e Zvidade Antioxidante da Polpa e Óleo Essencial da Pera do Cerrado (Eugenia klotzschiana Berg.). 2016. Available online: https://repositorio.ifgoiano.edu.br/handle/prefix/42 (accessed on 20 October 2020).

17. Carneiro, N.S.; Alves, J.M.; Alves, C.C.F.; Esperandim, V.R.; Miranda, M.L.D. Essential oil of flowers from Eugenia klotzschiana (myrtaceae): Chemical composition and in vitro trypanocidal and cytotoxic activities. Rev. Virtual Quim. 2017, 9, 1381-1392. [CrossRef]

18. Mariano, A.P.X.; Ramos, A.L.C.C.; Augusti, R.; Araújo, R.L.B.; Melo, J.O.F. Analysis of the chemical profile of cerrado pear fixed compounds by mass spectrometry with paper spray and volatile ionization by SPME-HS CG-MS. Res. Soc. Dev. 2020, 9, e949998219. [CrossRef]

19. da Rocha, R.F.J.; da Silva Araújo, Í.M.; de Freitas, S.M.; dos Santos Garruti, D. Optimization of headspace solid phase microextraction of volatile compounds from papaya fruit assisted by GC-olfactometry. J. Food Sci. Technol. 2017, 54, 4042-4050. [CrossRef] [PubMed]

20. Sánchez-Hernández, E.; Buzón-Durán, L.; Andrés-Juan, C.; Lorenzo-Vidal, B.; Martín-Gil, J.; Martín-Ramos, P. Physicochemical characterization of Crithmum maritimum L. and Daucus carota subsp. gummifer (Syme) Hook. fil. and their antimicrobial activity against apple tree and grapevine phytopathogens. Agronomy 2021, 11, 886. [CrossRef]

21. Wei, C.; Ma, Z.; Liu, Y.; Qiao, J.; Sun, G. Effect of boron on fruit quality in pineapple. In AIP Conference Proceedings; AIP Publishing LLC: Melville, NY, USA, 2018.

22. Biajoli, A.F.P. Fibras para SPME (microextração em fase solida) Recobertas com Novos Ormosils Sol-gel. (Doctoral Dissertation, Universidade Estadual de Campinas (UNICAMP). Instituto de Química). 2008. Available online: http://repositorio.unicamp.br/ jspui/handle/REPOSIP/250195 (accessed on 20 July 2021). 
23. Pawliszyn, J. Theory of solid-phase microextraction. In Handbook of Solid Phase Microextraction; Elsevier: Amsterdam, The Netherlands, 2012; pp. 13-59. [CrossRef]

24. Sigma, S. SPME for GC Analysis: Getting Started with Solid Phase Microextraction; Merck: Darmstadt, Germany, 2018.

25. Canuto, K.; Garruti DD, S.; Magalhaes, H. Microextração em Fase Sólida: Métodos Analíticos Práticos Para Extração de Compostos Voláteis de Frutas. Embrapa Agroindústria Tropical-Comunicado Técnico (INFOTECA-E). 2011. Available online: https:/ / ainfo.cnptia.embrapa.br/digital/bitstream/item/42119/1/COT11003.pdf (accessed on 20 October 2020).

26. Silva, M.R.; Bueno, G.H.; Araújo, R.L.; Lacerda, I.C.; Freitas, L.G.; Morais, H.A.; Augusti, R.; Melo, J.O. Evaluation of the influence of extraction conditions on the isolation and identification of volatile compounds from cagaita (Eugenia dysenterica) using HS-SPME/GC-MS. J. Braz. Chem. Soc. 2019, 30, 379-387. [CrossRef]

27. García, Y.M.; Lemos, E.E.P.D.; Augusti, R.; Melo, J.O.F. Optimization of extraction and identification of volatile compounds from Myrciaria Floribunda. Rev. Ciência Agronômica 2021, 52, 1-8. [CrossRef]

28. Hui, Y.H.; Chen, F.; Nollet, L.M.; Guiné, R.P.; Martín-Belloso, O.; Mínguez-Mosquera, M.I.; Stanfield, P. (Eds.) Handbook of Fruit and Vegetable Flavors; John Wiley and Sons: Hoboken, NJ, USA, 2010.

29. Gasiński, A.; Kawa-Rygielska, J.; Szumny, A.; Czubaszek, A.; Gąsior, J.; Pietrzak, W. Volatile compounds content, physicochemical parameters, and antioxidant activity of beers with addition of mango fruit (Mangifera Indica). Molecules 2020, 25, 3033. [CrossRef]

30. Wu, Y.; Zhang, W.; Yu, W.; Zhao, L.; Song, S.; Xu, W.; Zhang, C.; Ma, C.; Wang, L.; Wang, S. Study on the volatile composition of table grapes of three aroma types. LWT 2019, 115, 108450. [CrossRef]

31. Xiao, Z.; Li, Q.; Niu, Y.; Zhou, X.; Liu, J.; Xu, Y.; Xu, Z. Odor-active compounds of different lavender essential oils and their correlation with sensory attributes. Ind. Crops Prod. 2017, 108, 748-755. [CrossRef]

32. Freitas, T.P.; Taver, I.B.; Spricigo, P.C.; do Amaral, L.B.; Purgatto, E.; Jacomino, A.P. Volatile Compounds and Physicochemical Quality of Four Jabuticabas (Plinia sp.). Molecules 2020, 25, 4543. [CrossRef] [PubMed]

33. Yang, L.; Zhu, Y.; He, Z.; Zhang, T.; Xiao, Z.; Xu, R.; He, J. Plantanone D, a new rare methyl-flavonoid from the flowers of Hosta plantaginea with anti-inflammatory and antioxidant activities. Nat. Prod. Res. 2021, 35, 4331-4337. [CrossRef] [PubMed]

34. Pawliszyn, J. Solid Phase Microextraction: Theory and Practice; John Wiley \& Sons: Hoboken, NJ, USA, 1997.

35. Krokou, A.; Kokkinofta, R.; Stylianou, M.; Agapiou, A. Decoding carob flavor aroma using HS-SPME-GC-MS and chemometrics. Eur. Food Res. Technol. 2020, 246, 1419-1428. [CrossRef]

36. Kataoka, H.; Lord, H.L.; Pawliszyn, J. Applications of solid-phase microextraction in food analysis. J. Chromatogr. A 2000, 880, 35-62. [CrossRef]

37. Garcia, C.V.; Stevenson, R.J.; Atkinson, R.G.; Winz, R.A.; Quek, S.Y. Changes in the bound aroma profiles of 'Hayward'and 'Hort16A'kiwifruit (Actinidia spp.) during ripening and GC-olfactometry analysis. Food Chem. 2013, 137, 45-54. [CrossRef]

38. Do Nascimento, A.F. Atividade do Óleo Essencial de Frutos de Schinus Terebinthifolius Raddi (Anacardiaceae) em Tetranychus urticae Koch (Acari: Tetranychidae) e Rhyzopherta dominica Fabricius (Coleoptera: Bostrichidae). 2012. Available online: http: //www.tede2.ufrpe.br:8080/tede2/handle/tede2/5951 (accessed on 20 January 2021).

39. Rondán Sanabria, G.G.; Cabezas Garcia, A.J.; Oliveira Lima, A.W.; Brousett-Minaya, M.A.; Narain, N. HS-SPME-GC-MS detection of volatile compounds in Myrciaria jabuticaba Fruit. Sci. Agropecu. 2018, 9, 319-327. [CrossRef]

40. Núñez-Carmona, E.; Abbatangelo, M.; Zottele, I.; Piccoli, P.; Tamanini, A.; Comini, E.; Sberveglieri, G.; Sberveglieri, V. Nanomaterial gas sensors for online monitoring system of fruit jams. Foods 2019, 8, 632. [CrossRef]

41. Asadi, K.; Abbasi-Maleki, S.; Hashjin, G.S. Antidepressant-like effect of Cuminum cyminum essential oil on the forced swim and tail suspension tests in male mice. J. Shahrekord Univ. Med. Sci. 2020, 22, 167-172. [CrossRef]

42. Boachon, B.; Burdloff, Y.; Ruan, J.-X.; Rojo, R.; Junker, R.R.; Vincent, B.; Nicolè, F.; Bringel, F.; Lesot, A.; Henry, L.; et al. A promiscuous CYP706A3 reduces terpene volatile emission from Arabidopsis flowers, affecting florivores and the floral microbiome. Plant Cell 2019, 31, 2947-2972. [CrossRef]

43. Thongkham, E.; Aiemsaard, J.; Kaenjampa, P. Antioxidant and Antimicrobial Properties of Ethanolic Extract of Asam Gelugor Fruit (Garcinia atroviridis). Burapha Sci. J. 2021, 26, 1293-1307.

44. Mei, L.; Shi, L.; Song, X.; Liu, S.; Cheng, Q.; Zhu, K.; Zhuge, R. Characterization of Carboxymethyl Cellulose Films Incorporated with Chinese Fir Essential Oil and Their Application to Quality Improvement of Shine Muscat Grape. Coatings 2021, 11, 97. [CrossRef]

45. Fang, H.; Chen, J.; Tian, Y.; Liu, Y.; Li, H.; Cheng, H. Chemometrics characterization of volatile changes in processed bayberry juice versus intact fruit during storage by headspace solid-phase micro-extraction combined with GC-MS. J. Food Processing Preserv. 2020, 44, e14444. [CrossRef]

46. Cano-Lamadrid, M.; Galindo, A.; Collado-González, J.; Rodríguez, P.; Cruz, Z.N.; Legua, P.; Burló, F.; Morales, D.; CarbonellBarrachina, Á.A.; Hernández, F. Influence of deficit irrigation and crop load on the yield and fruit quality in Wonderful and Mollar de Elche pomegranates. J. Sci. Food Agric. 2018, 98, 3098-3108. [CrossRef] 